\title{
MIGRACJE LUDNOŚCI PODCZAS RZYMSKIEGO PODBOJU GALII W LATACH 58-51 PRZED CHR. PRÓBA UJĘCIA HISTORYCZNO-ANTROPOLOGICZNEGO
}

\section{Michał Norbert Faszcza}

(1) http://orcid.org/0000-0003-3562-6217

Uniwersytet Śląski w Katowicach

\author{
ABSTRACT \\ MIGRATIONS DURING THE ROMAN CONQUEST OF GAUL \\ IN 58-51 BC: A HISTORICAL AND ANTHROPOLOGICAL APPROACH
}

Caesar's Commentarii de bello Gallico are a unique Roman source containing information on barbarian migrations in the $1^{\text {st }}$ century BC. Despite numerous studies dedicated to Caesar's narrative style, there still is a lack of reflection on the possible causes of migrations and the attitude of wandering barbarians to the Roman rule. Contemporary scholars have a tendency to see barbarians as Rome's 'eternal' enemies, and often assume that they 'must' have manifested aggressive attitudes. By incorporating anthropological reflection and adopting the 'other's' perspective, it is possible to better understand mechanisms prompting barbarians to look for a new homeland. No less of an important aspect is the reconstruction of Caesar's way of presenting the phenomenon of migration, which allows us to explain why he treated it as hostile in every case.

Keywords: Caesar, migrations, barbarians, historical anthropology.

Słowa kluczowe: Cezar, migracje, barbarzyńcy, antropologia historyczna.

Cezariańskie Commentarii de bello Gallico stanowią unikatowe w skali rzymskiego piśmiennictwa źródło pozwalające poznać mechanizmy barbarzyńskich migracji dokonujących się w Europie Zachodniej w I wieku przed Chr. ${ }^{1}$ W jego ujęciu każdorazowo stanowiły one zagrożenie dla władztwa rzymskiego, w związku z czym wymagały stosownej reakcji w postaci dania im zbrojnego odporu. Początkowe przekonanie o prawdomówności Gajusza Juliusza Cezara z czasem ustąpiło miejsca próbom

${ }^{1}$ Wszystkie kolejne daty związane $\mathrm{z}$ antycznymi wydarzeniami i postaciami odnoszą się do czasów przed narodzeniem Chrystusa, chyba że wyraźnie zaznaczono inaczej.

Adres do korespondencji: michalfaszcza@o2.pl 
przedstawienia jego twórczości w kategoriach narzędzia propagandy politycznej², a współcześnie Commentarii de bello Gallico stały się obiektem analizy koncentrującej się na stosowanych toposach i schematach narracyjnych. Z tego względu problematyka zderzenia kulturowego ${ }^{3}$ mającego miejsce w Galii w latach 58-51 zeszła na dalszy plan, choć wciąż nie udało się znaleźć satysfakcjonujących odpowiedzi na pytanie o motywy przyświecające migrantom i ich stosunek do Rzymu. Wydaje się bowiem, że w świetle postępującej refleksji nad zjawiskiem migracji w dziejach, będącej dziełem kolejnych pokoleń historyków, archeologów, socjologów i antropologów kulturowych, uproszczone opinie przekazane przez Cezara, który kierował się odmiennymi pobudkami niż dokładne przedstawienie czytelnikom specyfiki kulturowej Galów, Germanów czy Brytów, wymagają uzupełnienia polegającego na przyjęciu perspektywy „obcego”, czyli odwrócenia dotychczas dominującej optyki ${ }^{4}$.

Wyszedłem przy tym z założenia, że - nie negując sprawczości jednostek - przyczyn migracji należy raczej upatrywać w szerszych procesach społeczno-ekonomicznych, których nie da się ująć we właściwym kontekście bez uwzględnienia czynnika kulturowego. Nawet jeśli w Commentarii de bello Gallico przemieszczenia ludności w znacznym stopniu były pozbawione tego rodzaju tła, to i tak istnieje możliwość powiązania pozostawionych przez Cezara opisów z procesami zachodzącymi w ówczesnym Barbaricum, uchwytnymi dzięki pozostałym źródłom literackim i archeologicznym. Nie należy także zapominać, że niejako mimochodem sam prokonsul dostarczył istotnych poznawczo informacji pozwalających osadzić prezentowane przez niego zdarzenia w bardziej rozbudowanym kontekście.

\section{W POSZUKIWANIU NOWEJ OJCZYZNY}

Cezar pozostawił wzmianki na temat czterech zjawisk migracyjnych zachodzących w północnym Barbaricum. Trzy z nich doprowadziły do zbrojnej konfrontacji

${ }^{2}$ W szczególności: C.E. Stevens, The "Bellum Gallicum” as a Work of Propaganda, „Latomus” 1952, vol. 11, s. 3-18, 165-179; M. R a m b a u d, L'Art de la déformation historique dans les Commentaires de César, Paris 1953; J.H. Collin s, Caesar as Political Propagandist [w:] Aufstieg und Niedergang der römischen Welt, Bd. I.1, Hrsg. H. Te mporini, Berlin-New York 1972, s. 922-966. Na gruncie polskim: M.S. Popła w s ki, Polityczna publicystyka w dobie Cezara i Augusta, Lublin 1935, s. 63-73.

${ }^{3}$ Zastosowanie tego typu określenia nie wynika z braku wcześniejszych kontaktów, które w zależności od okresu zachodziły ze zmienną intensywnością: B. Cunliffe, Greeks, Romans \& Barbarians: Spheres of Interaction, London 1988, s. 38-124; P.S. We11s, Trade and Exchange [w:] The Celtic World, ed. M.J. Gree n, London-New York 1996, s. 230-241. Jego źródłem jest natomiast odmienny system wartości, rzutujący na postrzeganie niektórych zjawisk, nie wyłączając form podporządkowania politycznego i sposobu prowadzenia działań wojennych.

${ }^{4}$ Tego typu badania są prowadzone przede wszystkim odnośnie do ludów galijskich. Dobrym przykładem dekonstrukcji Cezariańskich twierdzeń opartych na dominujących tendencjach literackich jest: S.B. Dun ha m, Caesar's Perception of Gallic Social Structures [w:] Celtic Chiefdom, Celtic State: The Evolution of Complex Social Systems in Prehistoric Europe, eds. B. A rn old, D.B. G ib s o n, Cambridge 1995, s. 161-170. 
z Rzymem. Prokonsulowi przyszło mierzyć się z Helwetami i ich sojusznikami (58 r.), wieloetnicznymi siłami swebskiego władcy Ariowista (58 r.) oraz Uzypetami i Tenkterami (55 r.). Wspomniał ponadto o zasiedlaniu południowej Brytanii przez plemiona belgijskie, co tylko pośrednio było związane z przeprowadzonymi przez niego dwiema inwazjami na Wyspę (55 i 54 r. $)^{5}$. Można się domyślać, że był to tylko ułamek pierwszowiecznych przesunięć ludności, uwzględnionych przez Cezara tylko w takim zakresie, w jakim pozostawały w związku z toczonymi przez niego kampaniami. Świadczą o tym informacje o niedawnym osadnictwie kilku plemion germańskich na obszarze środkowej Galii ${ }^{6}$, jak również pojawieniu się tam odłamu Bojów zamieszkujących pierwotnie - co potwierdzają znaleziska archeologiczne Czechy i Morawy ${ }^{7}$. Kolejną przesłanką jest skład armii Ariowista, przy opisie której Cezar wymienił nazwy aż siedmiu plemion ${ }^{8}$.

W ujęciu Cezara istniały trzy motywy skłaniające barbarzyńców do rozpoczęcia wędrówki: przekonanie o własnej sile ${ }^{9}$, presja militarna ze strony sąsiadów ${ }^{10}$ i ambicje jednostek dążących do zdobycia władzy królewskiej ${ }^{11}$. Względem osiedlających się w Brytanii Belgów nie wskazał przyczyn zainicjowania tego procesu.

Pojawienie się migrantów na zamieszkałych terenach wiąże się zazwyczaj z narastaniem napięć, dlatego też nie powinno dziwić, że Helweci i ich sprzymierzeńcy starli się z Eduami, Ambarrami i Allobrogami ${ }^{12}$, drużyna Ariowista - z Sekwanami i Eduami ${ }^{13}$, Uzypetowie i Tenkterowie - z Menapiami, Eburonami, Kondrusami i Trewerami ${ }^{14}$, zaś Belgowie - z bliżej nieokreślonymi mieszkańcami południowej Brytanii $^{15}$. Niewykluczone, że to właśnie powyższa prawidłowość wpłynęła na sportretowanie przez Cezara migrujących plemion jako nieuchronnie prowokujących konflikty, a zatem stanowiących potencjalne zagrożenie dla władztwa rzymskiego. Co więcej, opisywanie migracji w kategoriach uwarunkowań polityczno-militarnych, odnoszących się także do powodów rozpoczęcia wędrówki, w naturalny sposób mogło wynikać ze skupienia się na ostatnim akordzie procesu - wejściu w kontakt z prokonsulem i jego wojskiem.

Cezar nie uwzględnił jednak dodatkowego aspektu, a mianowicie wyczerpywania się zasobów niezbędnych do funkcjonowania modelu społeczno-politycznego

${ }^{5}$ Caes., $B G, 4.20 .1-2$ w związku z: $B G, 2.4 .6-8,5.12 .1-3$. Por. Strab., 4.4.1.

${ }^{6}$ Caes., $B G, 4$.10.4. Por. Strab., 4.3.4.

7 Caes., BG, 1.5.4, 1.25.6, 1.28.5, 1.29.2; Strab., 5.1.6; Tac., Ger., 28; G. D ob e s ch, Anmerkungen zur Wanderung der mitteleuropäischen Boier, „Tyche” 1993, Bd. 8, s. 9-17; J. B o uzek, The Story of Boii [w:] Boier zwischen Realität und Fiktion, Hrsg. M. Karwows ki, M. Salač, S. Sievers, Bonn 2015, s. 26-27, 33-38. W przypadku Bojów poszukiwanie nowych siedzib było konsekwencją zbrojnej ekspansji germańskich Kwadów i Markomanów.

${ }^{8}$ Caes., $B G, 1.51 .2$. Takoż: Oros., 6.7.7, który skopiował tę informację z dzieła Cezara.

${ }^{9}$ Caes., $B G, 1.2 .3-5$ (Helweci), być może pośrednio także: $B G, 5.12 .1-3$ (Belgowie).

${ }^{10}$ Caes., $B G, 1.1 .4-5$ (Helweci), 4.1.1-4 (Uzypetowie i Tenkterowie).

${ }^{11}$ Caes., $B G, 1.3-5$ (Orgetorix z plemienia Helwetów), 1.31.10-16 (Ariowist).

12 Caes., BG, 1.11.1-6.

${ }^{13}$ Caes., $B G, 1.31 .4-13$.

${ }^{14}$ Caes., $B G, 4.4 .2-3,4.6 .4-5$.

${ }^{15}$ Caes., $B G, 2.4 .6-8,5.12 .1-3$. 
przyjętego przez daną wspólnotę. Bez względu na to, czy opisany przez niego sposób podejmowania decyzji spełniał kryteria przypisywane „plemieniu” (Helweci, Uzypetowie i Tenkterowie) czy „wodzostwu” (Ariowist, część Belgów) ${ }^{16}$, to sposób regulacji stosunków wewnętrznych opierał się w znacznej mierze na alimentacji i redystrybucji zasobów, bądź to dokonywanej względem rodowców, bądź to innych członków wspólnoty, często pozostającej w związku ze stosunkiem klienteli ${ }^{17}$. Jakiekolwiek zaburzenia przepływu przedmiotów stanowiących wyróżnik elity (czyli głównie importów śródziemnomorskich) czy choćby długotrwały brak nadwyżek rolnych mogły przyczynić się do osłabienia, a nawet załamania dotychczasowych sieci zależności. W takich przypadkach nieuchronnie pojawiali się nowi pretendenci do objęcia przywództwa nad zbiorowością, ale przede wszystkim - bez względu na to, czy w roli inicjatora występowała „stara” elita, czy też jej następcy - konieczne stawało się zdobycie dostępu do dóbr zapewniających utrzymanie statusu, nie wyłączając wypraw łupieżczych.

Ścisłe powiązanie tych dwóch aspektów (dominacji społecznej i ekonomii) dało efekt w postaci powstania tak zwanej prestige goods economy, podporządkowanej pozyskiwaniu przedmiotów wykorzystywanych do konstruowania bądź utrwalania stratyfikacji społecznej ${ }^{18}$. W takich przypadkach wojna mogła służyć nie tyle siłowemu rozwiązywaniu konfliktów, ile regulacji stosunków wewnętrznych ${ }^{19}$.

Poszukiwanie nowego bądź lepszego dostępu do importów napływających z południa, względnie przejęcie kontroli nad szlakami handlowymi umożliwiające zintensyfikowanie ich pozyskiwania i czerpanie dodatkowego dochodu $z$ ceł $\mathrm{i}$ organizacji wymiany handlowej, nie musiało wynikać wyłącznie z powstałego kryzysu. Nietrudno sobie wyobrazić sytuację, gdy ambicje poszczególnych rodów, a nawet niemożliwe do zrealizowania w zastanych warunkach ambicje młodszych synów przekładały się na finansowanie prywatnych przedsięwzięć wojennych. Cezar wspomniał zresztą o takim zjawisku zachodzącym u Germanów ${ }^{20}$. W takich przypadkach charyzmatyczne jednostki byłyby w stanie skupić wokół siebie grupę osób gotowych pomóc im w zyskaniu sławy wojennej i niezbędnych dóbr. Wydaje się zatem, że ogólne stwierdzenie Cezara o ambicji jako jednej z głównych przyczyn migracji zyskuje solidną podbudowę, tyle tylko, że pozostawała ona w ścisłym związku ze sposobem budowania pozycji społecznej wśród społeczności północnego Barbaricum.

${ }^{16}$ Na temat cech wyróżniających obie formy organizacji politycznej: T.C. Le w elle n, Antropologia polityczna. Wprowadzenie, tłum. A. Dąbrowska, T. Sieczkow ski, Kraków 2010, s. 34-35, 41-43 (plemię), 47-50 (wodzostwo).

${ }_{17}$ M.D. S ahlin s, On the Sociology of Primitive Exchange [w:] The Gift: An Interdisciplinary Perspective, ed. A.E. Ko mter, Amsterdam 1996, s. 27. Alimentacja wśród Galów: B. Cunliffe, Greeks, Romans \& Barbarians, s. 89-90; J.-L. Brun a ux, Les Gaulois, Paris 2005, s. 91. Wśród Germanów: R. Wenskus, Stammesbildung und Verfassung. Das Werden der frühmittelalterlichen gentes, KölnGraz 1961, s. 355; M. Todd, The Early Germans, Oxford 2004, s. 30.

${ }_{18}$ B. Cunliffe, Greeks, Romans \& Barbarians, s. 81-97; T. Earle, How Chiefs Come to Power: The Political Economy in Prehistory, Stanford 1997, s. 209-210.

${ }_{19}$ Zob. R.B. Fergus on, Explaining War [w:] The Anthropology of War, ed. J. Ha as, Cambridge 1990, s. 30, 40-43.

${ }^{20}$ Caes., BG, 6.23.7-8. Por. Tac., Ger., 6, 13-14. 
Katalizatorem takich ruchów mogły być długotrwałe wojny lub migracje sąsiednich plemion powodujące efekt domina. Kierunek przesiedleń nie był zdeterminowany „obiektywnymi” czynnikami, lecz wynikał z takich aspektów jak: siła ludów zamieszkujących wybrany obszar, bliskość kulturowa, możliwość zdobycia niezbędnych surowców, klimat itd. Parcie na południe było niewątpliwie uzasadnione uwarunkowaniami środowiskowymi, ale nie należy lekceważyć tego, że wiązało się również z lepszym dostępem do przedmiotów wytwarzanych w kręgu cywilizacji śródziemnomorskiej. W takim ujęciu Rzym jawił się nie jako przeciwnik, ale atrakcyjny partner handlowy. Nieco paradoksalnie, stopniowe przesuwanie się granic władztwa rzymskiego zmieniło zasięg i dotychczasowe kanały dystrybucji ${ }^{21}$, co zaburzało dotychczasowe układy i mogło dodatkowo motywować barbarzyńskie elity do zmiany miejsca zamieszkania. Kruchość i niestabilność systemu zależności międzyplemiennych powodowała, że każde poważne zaburzenie wyzwalało ciąg zdarzeń skutkujących wojnami, masakrami całych społeczności ${ }^{22}$, migracjami i wymianą elit. „Miraż południa” kusił co raz to kolejne ludy, ale Rzymianie najprawdopodobniej dostrzegali jedynie wierzchołek góry lodowej.

Gdyby zaakceptować wyjaśnienie Cezara, który wśród przyczyn rozpoczęcia migracji przez Helwetów wymienił ustawiczne walki toczone $z$ Germanami ${ }^{23}$, a następnie powiązać to z odnotowanym przez niego naporem Swebów (będących dla niego po prostu zbiorczą nazwą załabskich Germanów, traktowanych - wobec braku szczegółowych informacji - jako jednolite plemię ${ }^{24}$ ) na zachód ${ }^{25}$, to mogłoby się okazać, że w 58 roku zetknął się on z konsekwencjami znacznych przemieszczeń ludnościowych zachodzących w Europie Środkowowschodniej. Odległe echa wieści na ten temat już wcześniej docierały do Rzymu i można je odnaleźć w korespondencji prowadzonej przez Marka Tulliusza Cycerona, choć nie zdawano sobie sprawy z ich skali i przy$\operatorname{czyn}^{26}$. Po rozbiciu Helwetów kolejnymi etapami działań Cezara były zlikwidowanie królestwa założonego w środkowej Galii przez legitymującego się swebskim pochodzeniem Ariowista, a następnie masakra Uzypetów i Tenkterów, którzy przekroczyli Ren, uchodząc przed naporem Swebów. Nietrudno zauważyć, że wszystkie trzy wspomniane epizody wiązały się z napływem do Galii wschodnich Germanów.

Nie mniej ważne od świadectwa Cezara jest uchwycenie zachodzących przemian w materiale archeologicznym, czego faktycznie udało się dokonać, jeśli chodzi o wschodnich Germanów. Dzięki temu potwierdzono, że w I wieku doszło do przesunięcia ludności kultury przeworskiej w kierunku Hesji połączonego z występowaniem nad Renem i Mozelą przedmiotów z nią utożsamianych - zbiegło się to

${ }^{21}$ B. Cunliffe, Greeks, Romans \& Barbarians, s. 53-58, 71-79, 81-105.

22 Taki los spotkał m.in. germańskich Ampsywariów i Brukterów, którzy w I w. po Chr. zostali wyparci ze swoich siedzib i wybici podczas nieudanego poszukiwania nowej ojczyzny (Tac., Ger., 33; Ann., 13.55-56).

${ }^{23}$ Caes., $B G, 1.1 .4-5$.

${ }^{24}$ Podsumowanie dyskusji na temat znaczenia terminów „Swebia” i „Swebowie”: M.N. Fas scza, Kampania Cezara przeciwko Ariowistowi (58 r. przed Chr.), Oświęcim 2015, s. 35-50.

${ }^{25}$ Caes., $B G, 1.31 .10-16,1.37 .1-5,1.43 .9,1.44 .6,4.1 .4-5,6.10 .4-5$.

${ }^{26}$ Cic., ad Att., 1.19.2, 1.20.5, 2.21.11. 
W czasie z przesunięciem na zachód niektórych zbiorowości reprezentujących kulturę jastorfską ${ }^{27}$. Pojawienie się w Galii Ariowista musiało być zatem jednym z efektów parcia Swebów w kierunku ziem położonych bliżej Renu.

Mimo to błędem byłoby postrzeganie migrantów jako grup homogenicznych pod względem etnicznym. W przypadku Helwetów, tworzących raczej struktury segmentarne niż jednorodną politycznie zbiorowość ${ }^{28}$, Cezar wspomniał o towarzyszących im Raurakach, Tulingach, Latobrygach i Bojach ${ }^{29}$. Pod rozkazami Ariowista znajdowali się: Harudowie, Markomanowie, Trybokowie, Wangionowie, Nemetowie, Sedusjowie i Swebowie ${ }^{30}$. Uzypetowie wyruszyli w podróż wraz z Tenkterami ${ }^{31}$, a ponadto oba plemiona utrzymywały ścisłe kontakty z Sugambrami ${ }^{32}$. Wiadomo, że Brytanię zasiedlali między innymi Suessjonowie ${ }^{33}$, zaś najsilniejsze królestwo udało się utworzyć Atrebatom ${ }^{34}$. W kontekście specyfiki grup etnicznych nie było to niczym dziwnym, jako że konstruowanie samoidentyfikacji etnicznej ma charakter dynamiczny i nic nie stoi na przeszkodzie wytworzeniu nowego punktu odniesienia przy zachowaniu poprzedniego etnosu ${ }^{35}$. Skłania to do konstatacji, że kluczowego znaczenia nabierała wspólnota interesów i możliwość porozumienia się, co było szczególnie łatwe w warunkach egzystowania w ramach grupy młodych wojowników ${ }^{36}$. Kiedy więc Cezar pisał o migracji Helwetów i ich sprzymierzeńców, oznaczało to tyle, że w wieloetnicznej grupie Helweci stanowili dominujący komponent. Granica etniczna jest bowiem granicą o charakterze społecznym, mającym regulować i organizować

${ }^{27}$ K. Godłowski, Zu Besiedlungsveränderungen in Schlesien und den Nachbarräumen während der jüngeren vorrömischen Eisenzeit, „Zeszyty Naukowe Uniwersytetu Jagiellońskiego. Prace Archeologiczne" 1978, z. 26, s. 123-125; idem, Przemiany kulturowe i osadnicze w potudniowej $i$ środkowej Polsce $w$ młodszym okresie przedrzymskim $i$ w okresie rzymskim, Wrocław 1985, s. 139.

28 Caes., $B G, 1.12 .4-5,1.27 .4$.

${ }^{29}$ Caes., $B G, 1.5 .4,1.25 .6-7,1.26 .1-2,1.28 .3,1.28 .5,1.29 .2-3$.

30 Caes., $B G, 1.51 .2-3$.

31 Caes., $B G, 4.1 .1-2$.

32 Caes., $B G, 4.16 .3-4,4.18 .4$.

33 Caes., $B G, 2.4 .7$.

${ }^{34}$ M.N. Faszcza, Powstanie $i$ upadek brytońskiego królestwa Atrebatów [w:] Celtica. Studia $z$ dziejów Celtów, t. III, red. D. Was zak, Kalisz-Warszawa 2015, s. 13-19. Cezar nie wspomniał o migracji Atrebatów do Brytanii, a jedynie napomknął, że współpracujący z nim wówczas Commius cieszył się tam powszechnym poważaniem (Caes., BG, 4.21.8-9).

${ }^{35}$ F. Barth, Grupy i granice etniczne - spoleczna organizacja różnic kulturowych [w:] Badanie kultury. Elementy teorii antropologicznej. Kontynuacje, red. M. Kempny, E. Nowicka, thum. M. Głow a cka-Grajper, Warszawa 2004, s. 353-354, 361-365; P. He a ther, Imperia i barbarzyńcy. Migracje i narodziny Europy, tłum. J. Szczepań ski, Poznań 2010, s. 31-32; M. Fernán dez-Götz, Ethnische Interpretationen und archäologische Forschung: Entwicklung, Probleme, Lösungsansätze, „TÜVA Mitteilungen” 2013, Bd. 14, s. 59-76. Tego typu przypadki noszą nazwę „,rozproszonych tożsamości” (S. Fento n, Etniczność, tłum. E. Chomick k, Warszawa 2007, s. 15-16).

${ }^{36}$ Decydujące znaczenie należy przypisać wspólnemu językowi, będącemu jednym z fundamentów przekonania o wspólnocie kulturowej. Na temat teorii wspólnot komunikatywnych wykorzystywanej w badaniach poświęconych społecznościom pradziejowym: S. B rather, Ethnische Identitäten als Konstrukte der frühgeschichtlichen Archäologie, „Germania” 2000, Bd. 78, H. 1, s. 139-177; M. P ar c ze ws ki, Kultury archeologiczne a teoria wspólnot komunikatywnych [w:] Kultury archeologiczne a rzeczywistość dziejowa, red. S. Ta b a c zyń s k i, Warszawa 2000, s. 207-213. 
funkcjonowanie w obrębie wspólnoty, także powołanej na ograniczony czas w imię realizacji określonego celu - wówczas przybranie nowego etnosu przybiera postać strategii społecznej ${ }^{37}$.

Na czele każdej wspólnoty tego typu musiał stać przywódca (bądź grupa przywódców), integrujący ją pod względem politycznym na choćby najbardziej podstawowym poziomie. Może to dodatkowo tłumaczyć, dlaczego Cezar postrzegał niektóre migracje jako efekt monarchicznych aspiracji jednostek. Już Reinhard Wenskus zwrócił uwagę na okoliczność, że nowa grupa formowała się wokół jądra złożonego z elity, a następnie rozrastała według modelu kuli śniegowej - do „społeczeństwa w ruchu” przyłączały się po drodze kolejne osoby, które dostrzegły w tym korzyśćc ${ }^{38}$. Ponownie kieruje to uwagę badaczy na problem wieloetniczności, a zarazem tłumaczy, dlaczego Cezar odnotował udział w migracjach tak heterogenicznych zbiorowości.

\section{AGRESYWNI BARBARZYŃCY?}

Agresywność jako kategoria kulturowa mieściła się w ramach ogólnych wyobrażeń Greków na temat północnych barbarzyńców, szczególnie w obliczu doświadczeń wyniesionych z galijskich najazdów na Bałkany z III wieku ${ }^{39}$. W okresie nowożytnym pod wpływem ewolucjonizmu zaczęto postrzegać barbarzyńców na podobieństwo rdzennych społeczności pozaeuropejskich, którym pod wpływem przekonania o zgubnym wpływie pogaństwa na obyczaje przypisywano szczególną skłonność do okrucieństwa i wojowniczość ${ }^{40}$. W obu przypadkach tradycja historyczna była przekazywana w formie oralnej, w związku z czym - odwołując się do określenia Jacka Goody’ego - nastąpiła „kradzież historii”, polegająca na opisaniu dziejów podbitych ludów z perspektywy zwycięzców, przy zastosowaniu odmiennej „matrycy kulturowej" ${ }^{41}$. Sprawiło to, że na stereotypy odziedziczone po starożytności nałożyły się koncepcje powstałe pod wpływem ekspansji kolonialnej, dodatkowo wzmagając negatywny obraz północnych barbarzyńców i czyniąc oczywistymi ich agresywne inklinacje $\mathrm{e}^{42}$.

${ }^{37}$ F. B arth, Grupy i granice etniczne, s. 354; S. F ento n, Etniczność, s. 117; P. He a the r, Imperia i barbarzyńcy, s. 32 .

${ }^{38}$ R. We n s ku s, Stammesbildung und Verfassung, s. 113-142.

${ }^{39} \mathrm{Na}$ temat greckiego pojmowania „barbarzyńskości”: L. B o n fa n te, Classical and Barbarian [w:] The Barbarians of Ancient Europe: Realities and Interactions, ed. eadem, Cambridge 2011, s. 21-25; K. Vlass o poulos, Greeks and Barbarians, Cambridge 2013, s. 161-224.

40 J. Webster, Ethnographic Barbarity: Colonial Discourse and "Celtic Warrior Societies" [w:] Roman Imperialism: Post-Colonial Perspectives, eds. J. We b ster, J. Co o p er, Leicester 1996, s. 111123; A. Ku u er, Wymyślanie społeczeństwa pierwotnego. Transformacje mitu, thum. T. S i e c zkow s ki, A. Dąbrows k a, Kraków 2009, s. 21-37, 41-85.

${ }^{41}$ Zob. J. Good y, Kradzież historii, tłum. J. Do brow ols ki, Warszawa 2009.

${ }^{42}$ Takie przekonanie wynikało z definiowania „cywilizacji” wyłącznie przez pryzmat markerów wytworzonych w obrębie kultury śródziemnomorskiej, co bezpośrednio przekładało się na negatywne waloryzowanie dokonań ludów barbarzyńskich. 
Proste przenoszenie na Rzymian greckiej koncepcji „barbarzyńskości” nie wydaje się przy tym zasadne, a to za sprawą ich specyficznego podejścia do wojny, będącej jednym z najważniejszych narzędzi służących regulowaniu stosunków wewnętrznych, pozostającym w ścisłym związku z systemem politycznym republiki ${ }^{43}$. Trudno zatem zakładać, że ekspansywność mogła być dla Rzymian cechą decydującą o negatywnym postrzeganiu danej zbiorowości. Zamiast tego rozwinęli oni koncepcję „wojny sprawiedliwej” (bellum iustum), z czasem wykorzystywaną do uzasadniania konieczności dokonywania kolejnych podbojów ${ }^{44}$. Wziąwszy do tego pod uwagę typowe dla Kwirytów postrzeganie „obcego”, opierające się nie tyle na determinizmie językowo-geograficznym, ile na akcentowaniu postaw wobec wartości uznanych za podstawowe dla trwania rzymskiej wspólnoty (także względem Hellenów, którzy stworzyli ideę „barbarzyńcy” ${ }^{45}$, jasne jest, że nie samo wszczęcie wojny, lecz jej uzasadnienie odgrywało decydującą rolę.

Galijscy przeciwnicy Cezara nie zostali przez niego przedstawieni jako szczególnie agresywni, za to w treści Commentarii można odnaleźć ślady oszczędnych wyrazów uznania wobec ich dzielności ${ }^{46}$. Co jakiś czas starał się wpływać na odczucia czytelników poprzez wykorzystywanie głęboko zakorzenionego w rzymskim społeczeństwie strachu przez Galami (metus Gallicus), jak również odwoływanie do inwazji Cymbrów i Teutonów z lat 113-101, choć miało to służyć uzasadnianiu działań zaczepnych podejmowanych wobec barbarzyńców, nie zaś budowaniu dychotomii agresywni Galowie/Germanie - pokojowo nastawieni Kwiryci ${ }^{47}$. Prowadzi to do wniosku, że źródłem rzekomo wrogiej postawy migrantów było samo pojawienie się w pobliżu granic władztwa rzymskiego bez uzyskania na to uprzedniej zgody, co każe zadać pytanie: dlaczego mieliby w ogóle o taką zgodę zabiegać?

Kluczem do udzielenia na nie odpowiedzi zdaje się leżące u podstaw republikańskiego imperializmu przekonanie, że przeznaczeniem dziejowym Rzymu jest panowanie nad innymi ludami. Najpełniej zostało ono wyrażone przez Cycerona i Publiusza Wergiliusza Marona ${ }^{48}$. W myśl tej idei każdy sprzeciw wobec rzymskich pretensji do sprawowania zwierzchnictwa nosił znamiona „buntu” (seditio) bądź wrogiego

${ }^{43}$ W.V. Harris, War and Imperialism in Republican Rome 327-70 B.C., Oxford 1985, s. 54-104; J. Rich, Fear, Greed and Glory: The Causes of Roman War-Making in the Middle Republic [w:] War and Society in the Roman World, eds. J. Rich, G. Shipley, London-New York 1993, s. 38-66.

${ }^{44}$ H. Drexler, Iustum Bellum, „Rheinisches Museum für Philologie” 1959, Bd. 102, s. 97-140; J. Rüpke, Domi militiae. Die religiöse Konstruktion des Krieges in Rom, Stuttgart 1990, s. 117-123; M.S. Popławski, Bellum Romanum. Sakralność wojny i prawa rzymskiego, Lublin 2011, s. 21-77 (o rytuale wypowiadania wojny sprawiedliwej).

45 P. Vey ne, »Humanitas«: Romani e no [w:] L'uomo romano, cur. A. Giardina, Roma-Bari 1989, s. $385-415$.

${ }^{46}$ Zob. M. Rambaud, L'Art de la déformation..., s. 301-333; L. Rawling s, Caesar's Portrayal of Gauls as Warriors [w:] Julius Caesar as Artful Reporter: The War Commentaries as Political Instruments, eds. K. We1ch, A. Powe11, Swansea 1998, s. 171-192.

${ }^{47}$ Caes., $B G, 1.12 .4-7,1.14 .7,1.33 .40,1.40 .5,2.1 .1-4,2.4 .2,2.29 .4,7.77 .12,7.77 .14$. Na temat zjawiska metus Gallicus: H. Bellen, Metus Gallicus - Metus Punicus. Zum Furchtmotiv in der römischen Republik, Stuttgart 1985; D. Ran ki n, Celts and the Classical World, London-New York 1996, s. 103-146.

${ }^{48}$ Cic., Pro Sest., 104; Verg., Aen., 6.851-853. 
„sprzysiężenia” (coniuratio), co znalazło szczególnie silne odbicie w piśmiennictwie Cezara $^{49}$. Rzecz jasna można to potraktować jako wyraz określonej tendencji literackiej, która nie przekładała się na sposób prowadzenia polityki zagranicznej, ale dla czytelnika Commentarii musiało pozostawać oczywiste, że społeczność, która nigdy nie zetknęła się z władzą rzymską, nie jest zobligowana do zachowania wobec niej posłuszeństwa - aby taka argumentacja odniosła spodziewany skutek, musiała odwoływać się do szeroko rozpowszechnionego przekonania ${ }^{50}$. Niezdający sobie sprawy z tego rysu rzymskiej mentalności migranci nagminnie popełniali błąd, uważając, że konflikt interesów uda im się rozstrzygnąc na drodze negocjacji prowadzonych z uznaniem równej pozycji stron ${ }^{51}$.

W trakcie lektury Cezariańskich opisów wojen zwraca uwagę fakt, że w żadnym z przypadków migranci nie byli stroną inicjującą konflikt. Co więcej, budzący silne emocje Cymbrowie, uchodzący wraz z Teutonami za symbol barbarzyńskiej grozy, także jako pierwsi nie zaatakowali Rzymian, lecz w 113 roku zostali podstępem zmuszeni do stoczenia bitwy pod Noreją ${ }^{52}$.

Cezar nie zarzucał Helwetom i ich sojusznikom naruszenia granic Prowincji czy zaatakowania stacjonujących tam wojsk, a mimo to i tak musieli stawić czoła wrogiej postawie rzymskiego wodza, który pod pozorem negocjacji pokojowych wykorzystał zyskany czas na wzmocnienie armii ${ }^{53}$. Migranci musieli zdawać sobie sprawę, że stoją przed alternatywą: odwrót albo zbrojna konfrontacja, co zresztą zostało wprost wyrażone w ostatecznej odpowiedzi Cezara na wystosowaną przez nich prośbę o możliwość pokojowego udania się na południowy zachód ${ }^{54}$. Znając rozmiar przedsięwzięcia podjętego przez Helwetów i ich aliantów ${ }^{55}$, prokonsul nie mógł liczyć na inne rozwiązanie niż siłowe, choć podany przez niego pretekst, którym była realizacja uchwały Senatu z 61 roku nakazującej namiestnikowi Prowincji udzielanie wsparcia sprzymierzeńcom (w tym przypadku: głównie Eduom) ${ }^{56}$, wydaje się niezbyt przekonująca w obliczu odrzucenia ich wcześniejszych apeli o pomoc ${ }^{57}$.

Podobnie scharakteryzował przyczyny wojny z Ariowistem, do której ten okazał się nieprzygotowany, mimo przypisywanych mu przez Cezara pychy i arogancji,

${ }^{49}$ Zob np. Caes., $B G, 2.1 .1-2,2.3 .2-4,3.17 .1-5,3.28 .1-2,4.38 .1$.

${ }^{50}$ P.A. Brunt, Laus Imperii [w:] Imperialism in the Ancient World, eds. P.D.A. Garnsey, C.R. Whittaker, Cambridge 1978, s. 159-191.

${ }^{51}$ Caes., $B G, 1.7 .3-6,1.13 .2-14.7,1.34-36,1.42-45,1.47 .1-6,4.7-9,4.11 .1-6,4.12 .1-6$.

${ }_{52}$ Strab., 5.1.8; Liv., Per., 63; Vell., 2.12.2; Plut., Mar., 16.5; App., Celt., 13.

${ }^{53}$ Caes., $B G, 1.6-7$. Wprawdzie Cezar utrzymywał, że trasa migracji wiodła przez terytorium Prowincji $(B G, 1.7 .1)$, ale w treści innego passusu przyznaje, że ostatecznie obrali inną drogę, leżącą poza zakresem władztwa rzymskiego $(B G, 1.9 .1-2)$.

${ }^{54}$ Caes., $B G, 1.14 .1-7$.

${ }^{55}$ Caes., $B G, 1.5 .1-4,1.29 .1-3$.

${ }^{56}$ Caes., $B G, 1.35 .4$.

${ }^{57}$ Caes., $B G, 1.31 .6-15,1.44 .8-13,6.12 .1-7$; Cic., De div., 1.49, 1.90; Pan. Lat., 8.57. Niewykluczone, że Cezar dążył po prostu do rewanżu na Helwetach za porażkę zadaną przez nich Rzymianom w 107 r. (Caes., BG, 1.7.4, 1.12.5-6, 1.13.2-3, 1.14.3; Liv., Per., 65; Tac., Ger., 37; App., Celt., 1.3; Oros., 5.15.23-24). 
mających dowodzić dążenia do konfrontacji ${ }^{58}$. W tym przypadku wystąpił jeszcze jeden zarzut, który zapoczątkował przekonanie, jakoby Germanie każdorazowo stanowili w Galii element wrogi, a przez to zagrażający także Rzymowi ${ }^{59}$. Gdyby jednak odsunąć na bok alarmującą wizję Cezara, mogłoby się okazać, że sam wspomniał o osadnictwie germańskich Nemetów i Tryboków mającym miejsce jeszcze przed utworzeniem państwa Ariowista, co stawia jej poprawność pod znakiem zapytania ${ }^{60}$. Podobnie jak Helweci, także swebski władca w końcu uzmysłowił sobie, że starcie jest nieuniknione, a Cezar zamierza wykorzystać jego niedawne przybycie i brak woli całkowitego podporządkowania się do wszczęcia wojny, mimo że to właśnie za jego konsulatu otrzymał w 59 roku tytuł przyjaciela ludu rzymskiego (amicus populi Romani $)^{61}$. Ariowistowi nie udało się przeprowadzić na czas pełnej mobilizacji i ściągnąć posiłków zza Renu, w związku z czym uległ rzymskiej przewadze ${ }^{62}$.

Wyparci na południe Uzypetowie i Tenkterowie w obliczu pojawienia się Cezara od razu przystąpili do negocjacji, wyrażając zgodę na osiedlenie się na wyznaczonych im ziemiach ${ }^{63}$. Zaniepokojeni kontynuowaniem marszu przez armię rzymską, poprosili o trzydniowy rozejm, aby w tym czasie mogli uzyskać odpowiedź od Ubiów, w granice których mieliby wkroczyć. Tymczasem Cezar nie zaprzestał marszu, co sugeruje, że dążył do zbrojnej konfrontacji ${ }^{64}$. Wydany przez niego rozkaz, na mocy którego konnica miała ograniczyć się do działań defensywnych do momentu nadciągnięcia głównych sił, stanowi dodatkowy argument przemawiający za poprawnością tej interpretacji, gdyż w przeciwnym razie nakazałby zachowanie wobec Uzypetów i Tenkterów odpowiedniego dystansu ${ }^{65}$. Cezar starał się przekonać czytelnika, że ze strony migrantów prośba o rozejm była zwykłym wybiegiem, służącym ściągnięciu do obozu rozproszonej konnicy ${ }^{66}$. Choć rzeczywiście znaczna część jazdy barbarzyńskiej nie wzięła udziału w decydującej bitwie, to o braku agresywnych zamiarów ze strony migrantów świadczy nie tylko ich całkowite nieprzygotowanie do starcia, ale także wysłanie do rzymskiego obozu starszyzny plemiennej

${ }^{58}$ Caes., $B G, 1.33 .1-2,1.33 .4-5,1.34 .1-4,1.35 .1-5,1.43 .4-9$. Podobnie: Plut., Caes., 19.2; Flor., 1.45.9-13. Ponadto Cezar sformułował wobec Ariowista trzy zarzuty mające dowodzić jego zdradzieckości. Pierwszy dotyczył spustoszenia przez sprzymierzonych z nim Harudów ziem należących do Eduów i ściągania posiłków zza Renu (Caes., $B G, 1.37 .1-5$; Cass. Dio, 38.35.1). Drugi odnosił się do rzekomego zorganizowania zasadzki (Caes., $B G, 1.42-46$ ). Trzeci z kolei traktował o uwięzieniu posłów wysłanych przez Cezara $(B G, 1.47 .1-6)$.

${ }^{59}$ Caes., $B G, 1.33 .3-5,6.24 .1-6$. Ewolucja takiego postrzegania stosunków galijsko-germańskich była ściśle związana z rozwojem nacjonalizmów i postawieniem znaku równości pomiędzy Galami a Francuzami oraz Germanami a Niemcami.

${ }^{60}$ Caes., BG, 4.10.4; Strab., 4.3.4.

${ }^{61}$ Plut., Caes., 19.1; App., Celt., 16-17; Cass. Dio, 38.34.3.

${ }^{62} \mathrm{Na}$ temat usilnego parcia Cezara do bitwy, jak również jej przebiegu: M.N. Fas scza, Kampania Cezara..., s. 91-125.

${ }^{63}$ Caes., $B G$, 4.7-9; Cass. Dio, 39.47.1-2.

${ }^{64}$ Caes., $B G, 4.11 .1-6$.

${ }^{65}$ Caes., $B G$, 4.11.6.

${ }^{66}$ Caes., $B G, 4.9 .2-3$. Po bitwie okazało się, że jazda znajdowała się wówczas na ziemiach Sugambrów (Caes., $B G, 4.16 .1-3$; Cass. Dio, 39.48.3). Nie wiadomo jednak, jakie zadania wykonywała. Cezar utrzymywał, że była zajęta grabieżą. 
mającej załagodzić niedawny incydent. Cezar nakazał aresztować przedstawicieli starszyzny, tym samym pozbawiając Germanów wszystkich dowódców ${ }^{67}$.

Wynika z tego, że migranci, z którymi Cezar wszedł w zbrojny zatarg, nie przejawiali wobec Rzymian agresji, dopóki nie zostali zmuszeni do walki. Budowanie na bazie Cezariańskiej narracji wizji hord germańskich zalewających Galię, a w związku z tym dywagacje, czy Galia stałaby się rzymska czy germańska, sprawiają wrażenie pozbawionych realnych podstaw. Poszukiwanie analogii do zmagań rzymsko-barbarzyńskich toczonych u schyłku cesarstwa jawi się jako głęboko ahistoryczne, przede wszystkim dlatego, że to Rzymianie byli w tym przypadku stroną agresywną. Bazując na zakorzenionych w społeczeństwie lękach i przeświadczeniu o wyższości rzymskich racji nad innymi, Cezar wcielał w życie „przeznaczenie Rzymu”, jakim było panowanie nad każdym, kto pozostawał w zasięgu jego miecza.

\section{PODSUMOWANIE}

Zainteresowanie Cezara przemieszczeniami ludności, nawet jeśli było związane wyłącznie $\mathrm{z}$ toczonymi przez niego kampaniami, stanowiło prawdziwy fenomen na gruncie rzymskiej literatury. Mimo przedstawienia okoliczności towarzyszących migracjom w uproszczony sposób w jego wywodach pobrzmiewa ślad przynajmniej ogólnej znajomości mechanizmów funkcjonowania barbarzyńskich społeczności, w których decydującego znaczenia nabierała stratyfikacja społeczna oparta na redystrybucji dóbr. Ze zjawiskiem tym można powiązać formułowane przez prokonsula zarzuty o dążenie do władzy królewskiej.

Cezar stanął w obliczu wieloetnicznych wędrówek najprawdopodobniej spowodowanych ruchami migracyjnymi dokonującymi się w Europie Środkowowschodniej, które zbyt często łączył ze Swebami, aby można było ów fakt zlekceważyć. Pojawienie się w Galii kolejnych grup migrantów, a nawet założenie własnego państwa przez Ariowista, świadczy o świadomych próbach zbliżenia się niektórych plemion do granic władztwa rzymskiego. Galijskie ziemie gwarantowały bowiem nie tylko lepsze warunki uprawy roli czy hodowli, ale także łatwiejszy dostęp do dóbr o charakterze prestiżowym, co mogło dodatkowo motywować wspólnoty, które pozbawiono dotychczasowych kanałów dystrybucji, a także co bardziej ambitne jednostki marzące o zdobyciu własnego władztwa.

Nie sposób przy tym przeoczyć, że migrujący barbarzyńcy nie byli stroną inicjującą działania wojenne, starali się rozwiązać powstałe napięcia na drodze negocjacji. Sugeruje to, że migranci nie zamierzali najeżdżać terenów znajdujących się pod rzymskim władaniem, usilne zaś szukanie analogii do najazdów galijskich z IV-III wieku nie znajdowało uzasadnienia i wynikało raczej ze stereotypów kulturowych oraz pamięci o przeszłych porażkach. Nawet wymieniani w charakterze odstraszającego przykładu Cymbrowie i Teutonowie nie zaatakowali Rzymian jako pierwsi.

${ }^{67}$ Caes., BG, 4.13.4-6; App., Celt., 18.4; Cass. Dio, 39.47.3. 
Wszystko to każe odejść od przekonania o szczególnie agresywnym nastawieniu barbarzyńców wobec Rzymu. Działania Cezara wskazują za to na istnienie odwrotnej prawidłowości.

\section{BIBLIOGRAFIA}

\section{Źródła}

App., Celt. - Appianus, Celtica

Caes., $B G-\mathrm{C}$ a e s a r, Commentarii de bello Gallico

Cass. Dio - Cas sius Dio, Historia Romana

Cic., ad Att. - Ci c e ro, Epistulae ad Atticum

Cic., De div. - Cic ero, De divinatione

Cic., Pro Sest. - Ci c er o, Pro Sestio

Flor. - Flor us, Epitomae de Tito Livio

Liv., Per. - Liviu s, Periochae

Oros. - Orosius, Historiarum adversum paganos libri VII

Pan. Lat. - Panegyrici Latini

Plut., Caes. - Plutarchus, Caesar

Plut., Mar. - Plutarchus, Marius

Strab. - Strabo, Geographica

Tac., Ann. - Tacitu s, Annales

Tac., Ger. - Tacitu s, De origine et situ Germanorum

Vell. - Velle i u s, Historia Romana

Verg., Aen. - Vergilius, Aeneis

\section{Monografie}

Bellen H., Metus Gallicus - Metus Punicus. Zum Furchtmotiv in der römischen Republik, Stuttgart 1985.

Brunaux J.-L., Les Gaulois, Paris 2005.

Cunliffe B., Greeks, Romans \& Barbarians: Spheres of Interaction, London 1988.

Earle T., How Chiefs Come to Power: The Political Economy in Prehistory, Stanford 1997.

Faszcza M.N., Kampania Cezara przeciwko Ariowistowi (58 r. przed Chr.), Oświęcim 2015.

Fenton S., Etniczność, tłum. E. Chomicka, Warszawa 2007.

Godłowski K., Przemiany kulturowe $i$ osadnicze $w$ południowej $i$ środkowej Polsce $w$ młodszym okresie przedrzymskim i w okresie rzymskim, Wrocław 1985.

Go ody J., Kradziez historii, tłum. J. D obrow ols ki, Warszawa 2009.

H a rri is W.V., War and Imperialism in Republican Rome 327-70 B.C., Oxford 1985.

He ath er P., Imperia i barbarzyńcy. Migracje i narodziny Europy, tłum. J. S zc ze pański, Poznań 2010.

Kuper A., Wymyślanie społeczeństwa pierwotnego. Transformacje mitu, tłum. T. Sieczkowski, A. Dąbrowska, Kraków 2009. 
Lew ellen T.C., Antropologia polityczna. Wprowadzenie, thum. A. Dą brow s k a, T. S i e c zkow ski, Kraków 2010.

Rankin D., Celts and the Classical World, London-New York 1996.

R a m b a d M., L'Art de la déformation historique dans les Commentaires de César, Paris 1953. Rüpke J., Domi militiae. Die religiöse Konstruktion des Krieges in Rom, Stuttgart 1990.

To dd M., The Early Germans, Oxford 2004.

Vlas s o p oulos K., Greeks and Barbarians, Cambridge 2013.

Wen skus R., Stammesbildung und Verfassung. Das Werden der frühmittelalterlichen gentes, Köln-Graz 1961.

\section{Prace zbiorowe}

B a rth F., Grupy i granice etniczne - społeczna organizacja różnic kulturowych [w:] Badanie kultury. Elementy teorii antropologicznej. Kontynuacje, red. M. Kempny, E. Nowicka, tłum. M. Głow a cka-Grajper, Warszawa 2004, s. 348-377.

Bonfante L., Classical and Barbarian [w:] The Barbarians of Ancient Europe: Realities and Interactions, ed. L. B on fante, Cambridge 2011, s. 1-36.

Bouzek J., The Story of Boii [w:] Boier zwischen Realität und Fiktion, Hrsg. M. Karw ow ski, M. S a lač, S. Si ever s, Bonn 2015, s. 23-42.

Brunt P.A., Laus Imperii [w:] Imperialism in the Ancient World, eds. P.D.A. Garnsey, C.R. Whittaker, Cambridge 1978, s. 159-191.

Collins J.H., Caesar as Political Propagandist [w:] Aufstieg und Niedergang der römischen Welt, Bd. I.1, Hrsg. H. Te m p or in i, Berlin-New York 1972, s. 922-966.

Dun ha m S.B., Caesar's Perception of Gallic Social Structures [w:] Celtic Chiefdom, Celtic State: The Evolution of Complex Social Systems in Prehistoric Europe, eds. B. A rnold, D.B. Gibs on, Cambridge 1995, s. 161-172.

F a z z za M.N., Powstanie i upadek brytońskiego królestwa Atrebatów [w:] Celtica. Studia $z$ dziejów Celtów, t. III, red. D. Wa s zak, Kalisz-Warszawa 2015, s. 12-27.

Fergus on R.B., Explaining War [w:] The Anthropology of War, ed. J. Ha as, Cambridge 1990, s. 26-55.

Parczewski M., Kultury archeologiczne a teoria wspólnot komunikatywnych [w:] Kultury archeologiczne a rzeczywistość dziejowa, red. S. Taba czyńs ki, Warszawa 2000, s. 207-213.

Popław ski M.S., Bellum Romanum. Sakralność wojny i prawa rzymskiego, Lublin 2011.

Popław ski M.S., Polityczna publicystyka w dobie Cezara i Augusta, Lublin 1935.

Rawlings L., Caesar's Portrayal of Gauls as Warriors [w:] Julius Caesar as Artful Reporter: The War Commentaries as Political Instruments, eds. K. Welch, A. Powell, Swansea 1998, s. 171-192.

Rich J., Fear, Greed and Glory: The Causes of Roman War-Making in the Middle Republic [w:] War and Society in the Roman World, eds. J. R i c h, G. S h i pley, London-New York 1993, s. 38-68.

S a hlin s M.D., On the Sociology of Primitive Exchange [w:] The Gift: An Interdisciplinary Perspective, ed. A.E. Ko mter, Amsterdam 1996, s. 26-39.

Vey ne P., »Humanitas«: Romani e no [w:] L'uomo romano, cur. A. G i ar d in a, Roma-Bari 1989, s. 385-415.

Webster J., Ethnographic Barbarity: Colonial Discourse and "Celtic Warrior Societies" [w:] Roman Imperialism: Post-Colonial Perspectives, eds. J. Webster, J. Cooper, Leicester 1996, s. 111-123. 
Wells P.S., Trade and Exchange [w:] The Celtic World, ed. M.J. Gre e n, London-New York 1996, s. 230-243.

\section{Czasopisma}

Brather S., Ethnische Identitäten als Konstrukte der frühgeschichtlichen Archäologie, „Germania” 2000, Bd. 78, H. 1, s. 139-177.

Dobesch G., Anmerkungen zur Wanderung der mitteleuropäischen Boier, „Tyche” 1993, Bd. 8, s. 9-17.

Drexler H., Iustum Bellum, „Rheinisches Museum für Philologie” 1959, Bd. 102, s. $97-$ 140.

Fernández-Götz M., Ethnische Interpretationen und archäologische Forschung: Entwicklung, Probleme, Lösungsansätze, „TÜVA Mitteilungen” 2013, Bd. 14, s. 59-76.

Godłowski K., Zu Besiedlungsveränderungen in Schlesien und den Nachbarräumen während der jüngeren vorrömischen Eisenzeit, „Zeszyty Naukowe Uniwersytetu Jagiellońskiego. Prace Archeologiczne" 1978, z. 26, s. 110-125.

Steven s C.E., The »Bellum Gallicum« as a Work of Propaganda, „Latomus” 1952, vol. 11, s. 3-18, 165-179. 